\title{
Chemical forms of cadmium in a calcareous soil treated with different levels of phosphorus-containing acidifying agents
}

\author{
Chunfa $\mathrm{Wu}^{\mathrm{A}, \mathrm{B}, \mathrm{E}}$, Shihong Yan ${ }^{\mathrm{C}}$, Haibo Zhang $^{\mathrm{D}}$, and Yongming Luo ${ }^{\mathrm{D}}$ \\ ${ }^{A}$ Department of Agricultural Resources and Environment, Nanjing University of Information Science \\ and Technology, 219 Ningliu Road, Nanjing 210044, P.R. China. \\ ${ }^{B}$ Key Laboratory of Soil Environment and Pollution Remediation, Institute of Soil Science, \\ Chinese Academy of Sciences, 71 East Beijing Road, Nanjing 210008, P.R. China. \\ ${ }^{{ }^{C}}$ School of Earth and Environment, Anhui University of Science and Technology, Huainan 232001, P.R. China. \\ ${ }^{D}$ Yantai Institute of Coastal Zone Research, Chinese Academy of Sciences, 17 Chunhui Road, \\ Yantai 264003, P.R. China. \\ ${ }^{E}$ Corresponding author. Email: wchf1680@sina.com
}

\begin{abstract}
Calcareous soils with high background cadmium (Cd) levels are widely distributed in south-west China and soil acidity is a major environmental problem. However, little effort has been made to study the changes in chemical speciation as affected by soil acidification other than by acidic rain. In the present study, we investigated the impact of mono-ammonium phosphate (MAP) and phosphoric acid on soil $\mathrm{pH}$ and chemical transformation of $\mathrm{Cd}$ in calcareous soils. Calcareous soils collected from south-west China were treated with three concentrations $\left(0.1,0.2\right.$ and $0.4 \mathrm{~mol} \mathrm{~kg}^{-1}$ soil) of MAP and phosphoric acid, and without the addition of acidifying agent, before being incubated at $25 \pm 2{ }^{\circ} \mathrm{C}$ near field capacity moisture content for 60 days. The chemical forms of $\mathrm{Cd}$ in the soils were determined by the Tessier sequential extraction scheme. The concentration of $\mathrm{Cd}$ in the form bound to iron and manganese oxides $\left(\mathrm{Cd}_{\mathrm{FeOx}+\mathrm{MnOy}}\right)$ decreased significantly with increasing levels of the two acidifying agents, but the concentration of exchangeable $\mathrm{Cd}\left(\mathrm{Cd}_{\mathrm{Ex}}\right)$ exhibited a significant increase, indicating that the two acidifying agents can effectively promote the transformation of $\mathrm{Cd}_{\mathrm{FeOx}+\mathrm{MnOy}}$ to $\mathrm{Cd}_{\mathrm{Ex}}$. MAP may promote the same amount of $\mathrm{Cd}_{\mathrm{FeOx}+\mathrm{MnOy}}$ to $\mathrm{Cd}_{\mathrm{Ex}}$ as phosphoric acid at the same rate of addition, but the soil $\mathrm{pH}$ clearly differed, implying that an increase in water-soluble $\mathrm{P}$ with addition of acidifying agent may be one major factor affecting the chemical transformation of Cd. MAP and phosphoric acid should be used carefully as sources of water-soluble phosphorus for calcareous soils with high background concentrations of $\mathrm{Cd}$.
\end{abstract}

Additional keywords: chemical transformation, water-soluble phosphorus.

Received 15 July 2014, accepted 16 September 2014, published online 12 January 2015

\section{Introduction}

Cadmium $(\mathrm{Cd})$ is a heavy metal with high toxicity at very low concentrations (John et al. 1972; Friberg et al. 1974) and it is one of the most common soil pollutants (Bloemen et al. 1995; Andreu and Gimeno-Garcia 1996; Udom et al. 2004). In general, the toxicity of $\mathrm{Cd}$ in soil increases as its mobility increases. Previous studies have shown that the mobility of potentially hazardous trace metals in agricultural soils is closely related to the chemical transformations of these elements in the soil environment (Sposito et al. 1982; Navarro-Pedreño et al. 2003; Lafuente et al. 2008). It is therefore necessary to know the chemical forms of $\mathrm{Cd}$ in soils and the factors influencing the conversion of its chemical forms in soil.

Calcareous soils have high levels of calcium and magnesium carbonates formed largely by the weathering of calcareous rocks and fossil shell beds. These soils belong to Ustic Isohumisols according to the Chinese soil classification system (CSTCRGISS-CAS 1995) or to Cumulic Haplustolls based on the US system of soil classification (Soil Survey Staff 1996). Calcareous soils are widely distributed in Guangxi, Guizhou and Yunnan provinces in China, with very high background $\mathrm{Cd}$ concentrations in calcareous soils in some areas. In general, the mobility and bioavailability of $\mathrm{Cd}$ in calcareous soils are lower than in other soils (Agency for Toxic Substances and Disease Registry 2008). However, the mobility and bioavailability of $\mathrm{Cd}$ in calcareous soils will increase significantly with changes in some physical and chemical properties of the soil, such as decreasing soil $\mathrm{pH}$. Therefore, it is necessary to consider the problem of $\mathrm{Cd}$ activation in calcareous soils with high environmental background values.

It is well known that many physical and chemical properties of soil affect the chemical forms of $\mathrm{Cd}$, including soil $\mathrm{pH}$, soil solution ionic composition, the chloride concentration in the soil solution, cation exchange capacity, clay mineral content and types, organic matter content, calcium carbonate equivalent 
(CCE), oxides of iron (Fe), manganese (Mn) and aluminum and redox conditions (Haghiri 1974; Naidu et al. 1994; Yasrebi et al. 1994; Basta et al. 2001). Soil pH is one of the major physicochemical properties of soil and, to a great extent, controls the chemistry of $\mathrm{Cd}$ in the soil environment (Mann and Ritchie 1993). Increasing soil acidity is a major environmental problem in China and the use of acidifying agents, including some acidifying fertilisers, can greatly accelerate the rate of acidification in addition to acid rain (Guo et al. 2010). The acidifying fertilisers include fertilisers containing the ammonium $\left(\mathrm{NH}_{4}\right)$ form of nitrogen, such as ammonium nitrate, urea, ammonium phosphate, monoammonium phosphate (MAP) and ammonium sulfate. There have been numerous studies on the effects of acid rain on the mobility of heavy metals in non-calcareous soils (Siepak et al. 1999; Guo et al. 2005; Kim et al. 2010). However, little attention has been paid to the effects of soil acidification in the absence of acid rain on the chemical transformation of heavy metals in calcareous soils.

Sequential extraction has been used to identify the chemical forms of trace elements and predict their mobility and bioavailability (Tessier et al. 1979; Ahnstrom and Parker 1999). In sequential extraction techniques, a sample is treated with a series of progressively harsher reagents to dissolve increasingly recalcitrant forms. In the case of heavy metals, these methods operationally estimate the amounts of metals in various solid pools that are commonly termed exchangeable, carbonate bound, $\mathrm{Fe}$ and $\mathrm{Mn}$ oxide bound, organic and residual. Although several sequential extraction techniques have been in use for four decades (Gibbs 1973; Tessier et al. 1979), there are no universally accepted procedures in terms of reagents and their order in the sequence (Sutherland et al. 2000). The Tessier scheme is a typically sequential extraction method that can provide more information about $\mathrm{Cd}$ mobility and bioavailability for calcareous soils than other sequential extractions tested (Abbaspour et al. 2007; Jalali and Khanlari 2008; Khanmirzaei et al. 2013).

In the past three decades, the mobility of $\mathrm{Cd}$ has been studied in diverse soils, including acid (Simard et al. 1999; Cornu et al. 2001) and alkaline (Walter and Cuevas 1999; Navarro-Pedreño et al. 2003) soils. Nevertheless, there is limited information on the chemical transformation of $\mathrm{Cd}$ as a result of soil acidification caused by factors other than acid rain in calcareous soils with high $\mathrm{Cd}$ background concentrations. Phosphorus (P) is an essential nutrient element for plants and $\mathrm{P}$ deficiency in calcareous soils is a widespread problem in the cultivation of agricultural crops. It is therefore necessary to enhance $\mathrm{P}$ availability in many calcareous soils. MAP is an acidifying fertiliser that is often used in the blending of dry agricultural fertilisers and it can supply the soil with $\mathrm{N}$ and $\mathrm{P}$ in plantavailable forms. Phosphoric acid is increasingly used as a source of water-soluble $\mathrm{P}$ and is an acidifying agent that can enhance $\mathrm{P}$ availability in calcareous soils (Gharaibeh et al. 2010). The objectives of the present study were to evaluate the impact of the two P-containing acidifying agents (MAP and phosphoric acid) on soil $\mathrm{pH}$ and chemical transformations of $\mathrm{Cd}$ in calcareous soil and to study the potential factors affecting the chemical transformation of $\mathrm{Cd}$ in an incubation experiment.

\section{Materials and methods}

\section{Soil material}

The tested soil was collected from the surface horizon $(0-20 \mathrm{~cm})$ of an upland field under cultivation with agricultural crops. The sampling site was in Huanjiang County, Guangxi Zhuang Autonomous Region, China. The area is located at $25^{\circ} 5^{\prime} \mathrm{N}$, $107^{\circ} 59^{\prime} \mathrm{E}$ and is situated in the subtropical monsoon climatic zone with a temperate and humid climate throughout the year. The average annual temperature is $15.7^{\circ} \mathrm{C}$ and the mean annual precipitation is approximately $1750 \mathrm{~mm}$, with approximately $70 \%$ of the precipitation occurring from April to September. The soil collected was air dried and passed through a 2-mm sieve. The particle size distribution was determined by laser diffraction methods (Segal et al. 2009) and the textural class is clay loam (sand: 27.09\%; silt: 39.64\%; clay: 33.27\%) according to the US Department of Agriculture soil textural triangle (Soil Survey Division Staff 1993). Soil pH was measured with a $\mathrm{pH}$ meter (Sartorius Basic $\mathrm{pH}$ meter PB-10, Goettingen, Germany) with a soil: water ratio of $1: 2.5$. Soil organic matter was determined by wet oxidation at $180^{\circ} \mathrm{C}$ with a mixture of potassium dichromate and sulfuric acid (Agricultural Chemistry Committee of China 1983) and CCE was determined by neutralisation with $\mathrm{HCl}$ (Allison and Moodie 1965). Total concentrations of $\mathrm{Cd}, \mathrm{Fe}$ and $\mathrm{Mn}$ were determined by

Table 1. Sequential extraction steps as described by Tessier et al. (1979)

\begin{tabular}{|c|c|c|c|c|}
\hline Step & Chemical form & Symbol & Reagents & Time \\
\hline 1 & Exchangeable & Ex & $16 \mathrm{~mL}$ of $1.0 \mathrm{M} \mathrm{MgCl}_{2}(\mathrm{pH} 7)$ & $2 \mathrm{~h}\left(20 \pm 2^{\circ} \mathrm{C}\right)$ \\
\hline 2 & Bound to carbonates & Car & $\begin{array}{l}16 \mathrm{~mL} \text { of } 1.0 \mathrm{M} \mathrm{NaOAc} \text { (pH adjusted to } 5 \text { with } \\
\text { HOAc) }\end{array}$ & $6 \mathrm{~h}\left(20 \pm 2^{\circ} \mathrm{C}\right)$ \\
\hline 3 & $\begin{array}{l}\text { Bound to iron and manganese } \\
\text { oxides }\end{array}$ & $\mathrm{FeOx}+\mathrm{MnOx}$ & $\begin{array}{l}20 \mathrm{~mL} \text { of } 0.04 \mathrm{M} \mathrm{NH}_{2} \mathrm{OH} \cdot \mathrm{HCl} \text { in } 25 \%(\mathrm{v} / \mathrm{v}) \\
\mathrm{HOAc}\end{array}$ & $6 \mathrm{~h}\left(96 \pm 2^{\circ} \mathrm{C}\right)$ \\
\hline 4 & Bound to organic matter & $\mathrm{OC}$ & $\begin{array}{l}6 \mathrm{~mL} \text { of } 0.02 \mathrm{M} \mathrm{HNO}_{3} \text { and } 10 \mathrm{~mL} \text { of } 30 \% \\
\mathrm{H}_{2} \mathrm{O}_{2} \text { (pH adjusted to } 2 \text { with } \mathrm{HNO}_{3} \text { ), } 6 \mathrm{~mL} \\
\text { aliquot of } 30 \% \mathrm{H}_{2} \mathrm{O}_{2}(\mathrm{pH} \text { adjusted to } 2 \text { with } \\
\left.\mathrm{HNO}_{3}\right), 10 \mathrm{~mL} \text { of } 3.2 \mathrm{M} \mathrm{NH} \mathrm{NAc}_{4} \text { in } 20 \% \\
(\mathrm{v} / \mathrm{v}) \mathrm{HNO}_{3}\end{array}$ & $\begin{array}{c}2 \mathrm{~h}\left(85 \pm 2^{\circ} \mathrm{C}\right), 3 \mathrm{~h}\left(85 \pm 2^{\circ} \mathrm{C}\right), \\
0.5 \mathrm{~h}\left(20 \pm 2^{\circ} \mathrm{C}\right)\end{array}$ \\
\hline 5 & Residual & Res & $10 \mathrm{~mL}$ aqua regia, $5 \mathrm{~mL} 20 \%(\mathrm{v} / \mathrm{v}) \mathrm{HNO}_{3}$ & $\begin{array}{l}3 \mathrm{~h}\left(60^{\circ} \mathrm{C}\right), 2 \mathrm{~h}\left(125^{\circ} \mathrm{C}\right), 2 \mathrm{~h} \\
\left(150^{\circ} \mathrm{C}\right), 0.5 \mathrm{~h}\left(80^{\circ} \mathrm{C}\right)\end{array}$ \\
\hline
\end{tabular}


inductively coupled plasma mass spectrometry (ICP-MS) after digestion with aqua regia.

\section{Incubation experiment}

A $2 \times 3$ factorial experiment as a completely randomised design with three replicates was used to study the transformation of chemical forms of $\mathrm{Cd}$ in the calcareous soil with different levels of the two P-containing acidifying agents. Factors comprised the two P-containing acidifying agents (MAP and phosphoric acid) at three application rates $\left(0.10,0.20\right.$, and $0.40 \mathrm{~mol} \mathrm{~kg}^{-1}$ soil). In previous studies of heavy metal transformations, the incubation times ranged from several days to tens of weeks, but most were around 60 days (Mann and Ritchie 1994; Ma and Uren 1998; Lim et al. 2002; Lu et al. 2005; Rajaie et al. 2006). Therefore, an incubation period of 60 days was used in the present study. The experimental units were pots containing $100 \mathrm{~g}$ soil mixed with the P-containing acidifying agent. In addition, three pots of soil without acidifying agent were used as controls (CK). Enough distilled water was added to bring the soil moisture to near pot capacity. Pots were covered with Parafilm with a few holes to prevent rapid evaporation while allowing gaseous exchange. The pots were incubated at room temperature $\left(25 \pm 2^{\circ} \mathrm{C}\right)$. Soil moisture was maintained near field capacity by adding water to a constant weight once every 3 days. The soil in each pot was mixed well once every 7 days to maintain intimate contact with the acidifying agent. At the end of incubation, all the incubated soil samples were air dried and passed through a $2-\mathrm{mm}$ sieve. The chemical forms of Cd were determined by sequential extraction as described by Tessier et al. (1979) and indicated in Table 1. The concentrations of $\mathrm{Cd}$ in the five chemical fractions were also determined by ICP-MS after they were extracted. Lake sediment for extractable trace elements (GBW07436) that was obtained from National Research Center for Certified Reference Material (Beijing, China) was used to compare recovery based on sequential extraction with certified values, and the mean recovery of total $\mathrm{Cd}$ (the sum of the five individual chemical fractions) was $92.6 \pm 12.7 \%$. To evaluate the acidification effects of the two $\mathrm{P}$-containing acidifying agents on the calcareous soil, the $\mathrm{pH}$ values of all the incubated soil samples were also determined by a $\mathrm{pH}$ meter (Sartorius Basic $\mathrm{pH}$ meter PB-10) with a soil : water ratio of $1: 2.5$.

\section{Statistical analysis}

To characterise the relationship between chemical transformation of $\mathrm{Cd}$ and soil $\mathrm{pH}$ and the level of added $\mathrm{P}$ containing acidifying agent, simple linear regression analysis and multiple stepwise regression were used. Descriptive statistics was used to compare the three observations of three replicates for each treatment. In the present study, both descriptive statistics and regression analysis were performed using SPSS for Windows version 13 (SPSS Inc., Chicago, IL, USA).

\section{Results and Discussion}

\section{Soil properties}

The properties of the tested soil are given in Table 2, which shows that the soil was slightly alkaline and with a low CCE. The soil may have been slightly alkaline because of the low concentration of calcium carbonate $\left(\mathrm{CaCO}_{3} ; 10.4 \%\right)$, with a large proportion of the carbonates washed out from the surface horizon. The concentration of total $\mathrm{Cd}$ in the soil was very high and was approximately 33 times as high as the guideline value of the Chinese Environmental Quality Standard for Soils (GB 15618-1995) (www.zhb.gov.cn/english/ chanel-5/GB15618-1995.doc) for total Cd $\left(0.30 \mathrm{mg} \mathrm{kg}^{-1}\right)$. The chemical form of $\mathrm{Cd}$ in the soil was also analysed and most of

Table 2. Selected chemical and physical properties of the test soil $\mathrm{SOM}$, soil organic matter; CCE, calcium carbonate equivalent

\begin{tabular}{lccccc}
\hline pH & SOM (\%) & CCE (\%) & \multicolumn{3}{c}{ Total metal concentration } \\
$\left(\mathrm{mg} \mathrm{kg}^{-1}\right)$ & & $\mathrm{Cd}$ & $\mathrm{Fe}$ & $\mathrm{Mn}$ \\
\hline 7.29 & 2.61 & 1.55 & 9.86 & 50903 & 7611 \\
\hline
\end{tabular}

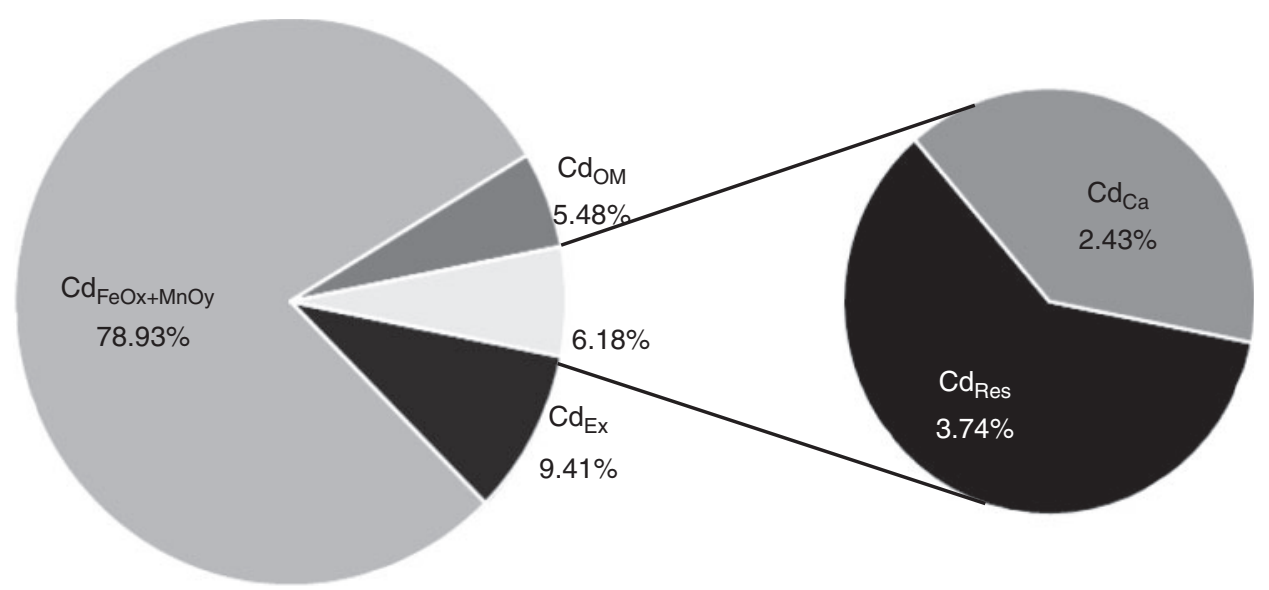

Fig. 1. Proportion of the five fractions of $\mathrm{Cd}$ in the untreated calcareous soil. $\mathrm{Cd}_{\mathrm{Ex}}$, exchangeable $\mathrm{Cd} ; \mathrm{Cd}$ ar $\mathrm{Cd}$ bound to carbonates; $\mathrm{Cd}_{\mathrm{FeOx}+\mathrm{MnOy}}, \mathrm{Cd}$ bound to iron and manganese oxides; $\mathrm{Cd} \mathrm{OM}_{\mathrm{OM}}, \mathrm{Cd}$ bound to organic matter; $\mathrm{Cd}_{\mathrm{Res}}$, residual $\mathrm{Cd}$. 
the $\mathrm{Cd}$ was only slightly available, being mostly bound to $\mathrm{Fe}$ and Mn oxides and not carbonates (Fig. 1). This result is consistent with the result of heavy metal analysis showing that the soil had high concentrations of $\mathrm{Fe}$ and $\mathrm{Mn}$ oxides and a low concentration of $\mathrm{CaCO}_{3}$. Although the exchangeable $\mathrm{Cd}\left(\mathrm{Cd}_{\mathrm{Ex}}\right)$ in the soil accounted for only $9.41 \%$ of total $\mathrm{Cd}$, the amount of $\mathrm{Cd}_{\mathrm{Ex}}$ was greater than that in normal soil. Thus, the migration and toxicity of $\mathrm{Cd}$ in the test soil require further investigation.

\section{Acidifying effects}

Although both phosphoric acid and MAP are P-containing acidifying agents, the acidifying effects of the two agents on the calcareous soil were significantly different (Fig. 2). The acidifying effect of phosphoric acid was significantly stronger than that of MAP and the $\mathrm{pH}$ of the soil decreased sharply with increasing application rate of phosphoric acid. This indicates that phosphoric acid is a strong acidifying agent, whereas MAP is a weak acidifying agent because it had good acid buffering capacity. It is well known that phosphoric acid is a

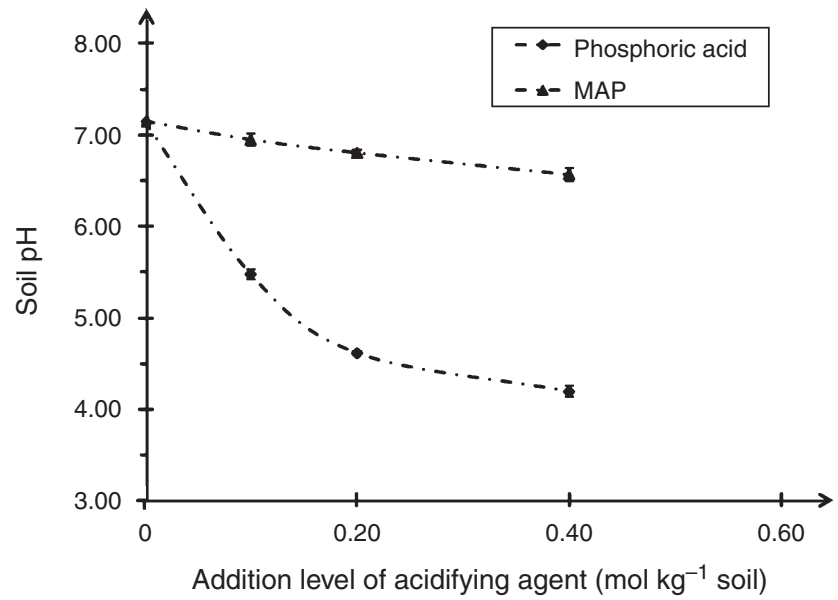

Fig. 2. Acidifying effects of phosphoric acid and mono-ammonium phosphate (MAP) on the calcareous soil. Data are the mean \pm s.d. of three observations. triprotic acid with three ionisable hydrogen atoms. The hydrogen ions are lost sequentially and the anions, after successive dissociation, are $\mathrm{H}_{2} \mathrm{PO}_{4}{ }^{-}, \mathrm{HPO}_{4}{ }^{2-}$ and $\mathrm{PO}_{4}{ }^{3-}$. Each successive dissociation step occurs with decreasing ease. Thus, $\mathrm{H}_{2} \mathrm{PO}_{4}^{-}$is a very weak acid and $\mathrm{HPO}_{4}{ }^{2-}$ is an extremely weak acid. MAP in soil can simultaneously provide $\mathrm{H}_{2} \mathrm{PO}_{4}^{-}$and $\mathrm{HPO}_{4}{ }^{2-}$ to the soil solution and this gives it a weak acidifying effect (Lu 2000).

\section{Chemical transformation of $\mathrm{Cd}$}

The chemical forms of $\mathrm{Cd}$ in the calcareous soil treated with different levels of P-containing acidifying agents are presented in Table 3. Cadmium in the fractions bound to iron and manganese oxides $\left(\mathrm{Cd}_{\mathrm{FeOx}+\mathrm{MnOy}}\right)$ and $\mathrm{Cd}_{\mathrm{Ex}}$ were the two dominant $\mathrm{Cd}$ fractions in the treated calcareous soil, whereas other fractions accounted for a small proportion. With increasing levels of acidifying agents, the concentration of $\mathrm{Cd}_{\mathrm{FeOx}+\mathrm{MnOy}}$ decreased significant, whereas the concentration of $\mathrm{Cd}_{\mathrm{Ex}}$ exhibited a significant increase with both acidifying agents (Fig. 3). This indicates that addition of both agents promoted the chemical transformation of $\mathrm{Cd}_{\mathrm{FeOx}+\mathrm{MnOy}}$ to $\mathrm{Cd}_{\mathrm{Ex}}$ in the calcareous soil. It was difficult to discriminate changes in the other three fractions (bound to carbonates, bound to organic matter and residual) among the treatments because of their low concentrations.

From Fig. 4 it can be seen that the concentration of $\mathrm{Cd}_{\mathrm{Ex}}$ had a tendency to decrease with soil $\mathrm{pH}$, whereas the concentration of $\mathrm{Cd}_{\mathrm{FeOx}+\mathrm{MnOy}}$ exhibited the opposite tendency. Soil $\mathrm{pH}$ is one of the most important factors affecting the sorption of $\mathrm{Cd}$ (Naidu et al. 1994) and the impact of changes in soil pH on the sorption of $\mathrm{Cd}$ on $\mathrm{Fe}$ and $\mathrm{Mn}$ oxides may perhaps explain, in part, the conversion of $\mathrm{Cd}$ chemical forms in the calcareous soil treated with P-containing acidify agents. From Figs 2 and 3, MAP promoted about the same amount of $\mathrm{Cd}_{\mathrm{FeOx}+\mathrm{MnOy}}$ to $\mathrm{Cd}_{\mathrm{Ex}}$ as phosphoric acid at the same application rate (in $\mathrm{mol} \mathrm{kg}^{-1}$ soil), whereas soil $\mathrm{pH}$ clearly differed between the two treatments. This indicates that soil $\mathrm{pH}$ is not the sole factor affecting the chemical transformation of $\mathrm{Cd}$ in the soil. Compared with MAP, phosphoric acid was more suitable for soil $\mathrm{pH}$ adjustment in the calcareous soil when considering the potential hazard of the $\mathrm{Cd}$

Table 3. Characterisation of the chemical forms of $\mathrm{Cd}$ in a calcareous soil treated with different application rates of phosphoric acid (P1, $0.1 \mathrm{~mol} \mathrm{~kg}^{-1}$ soil; $P 2,0.2 \mathrm{~mol} \mathrm{~kg}^{-1}$ soil; $P 3,0.4 \mathrm{~mol} \mathrm{~kg}^{-1}$ soil) and mono-ammonium phosphate (N1, $0.1 \mathrm{~mol} \mathrm{~kg}^{-1}$ soil; $\mathrm{N} 2,0.2 \mathrm{~mol} \mathrm{~kg}^{-1}$ soil; $\mathrm{N} 3,0.4 \mathrm{~mol} \mathrm{~kg}^{-1}$ soil)

Data are the mean \pm s.d. of three observations. The control group was treated with distilled water only. $\mathrm{Cd}_{\mathrm{Ex}}$, exchangeable $\mathrm{Cd} ; \mathrm{Cd}_{\mathrm{Ca}}, \mathrm{Cd}$ bound to carbonates; $\mathrm{Cd}_{\mathrm{FeOx}+\mathrm{MnOy}}, \mathrm{Cd}$ bound to iron and manganese oxides; $\mathrm{Cd}_{\mathrm{OM}}, \mathrm{Cd}$ bound to organic matter; $\mathrm{Cd}_{\mathrm{Res}}$, residual $\mathrm{Cd}$

\begin{tabular}{lccccc}
\hline Treatment & $\begin{array}{c}\mathrm{Cd}_{\mathrm{Ex}} \\
\left(\mathrm{mg} \mathrm{kg}^{-1}\right)\end{array}$ & $\begin{array}{c}\mathrm{Cd}_{\mathrm{Ca}} \\
\left(\mathrm{mg} \mathrm{kg}^{-1}\right)\end{array}$ & $\begin{array}{c}\mathrm{Cd}_{\mathrm{FeO}+\mathrm{MnOy}} \\
\left(\mathrm{mg} \mathrm{kg}^{-1}\right)\end{array}$ & $\begin{array}{c}\mathrm{Cd}_{\mathrm{OM}} \\
\left(\mathrm{mg} \mathrm{kg}^{-1}\right)\end{array}$ & $\begin{array}{c}\mathrm{Cd}_{\mathrm{Res}} \\
\left(\mathrm{mg} \mathrm{kg}^{-1}\right)\end{array}$ \\
\hline Control & $1.05 \pm 0.08$ & $0.24 \pm 0.05$ & $7.68 \pm 0.10$ & $0.52 \pm 0.02$ & $0.37 \pm 0.06$ \\
P1 & $1.93 \pm 0.13$ & $0.27 \pm 0.08$ & $6.84 \pm 0.13$ & $0.42 \pm 0.05$ & $0.40 \pm 0.03$ \\
P2 & $2.63 \pm 0.11$ & $0.32 \pm 0.06$ & $6.13 \pm 0.09$ & $0.37 \pm 0.03$ & $0.42 \pm 0.07$ \\
P3 & $3.66 \pm 0.04$ & $0.39 \pm 0.04$ & $5.01 \pm 0.12$ & $0.31 \pm 0.07$ & $0.47 \pm 0.02$ \\
N1 & $1.72 \pm 0.10$ & $0.25 \pm 0.07$ & $7.20 \pm 0.09$ & $0.33 \pm 0.04$ & $0.36 \pm 0.05$ \\
N2 & $2.42 \pm 0.09$ & $0.21 \pm 0.04$ & $6.58 \pm 0.15$ & $0.28 \pm 0.05$ & $0.37 \pm 0.04$ \\
N3 & $3.52 \pm 0.05$ & $0.17 \pm 0.03$ & $5.52 \pm 0.11$ & $0.20 \pm 0.04$ & $0.45 \pm 0.06$ \\
\hline
\end{tabular}




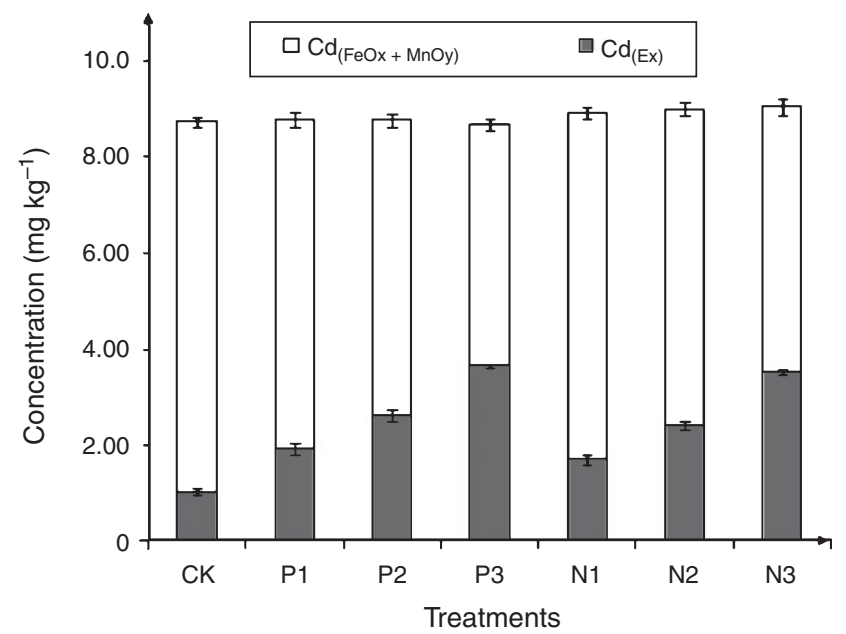

CK: soil treated with distilled water only

$\mathrm{P} 1$ : soil treated with $0.1 \mathrm{~mol}$ phosphoric acid $\mathrm{kg}^{-1}$ soil

P2: soil treated with 0.2 mol phosphoric acid $\mathrm{kg}^{-1}$ soil

P3: soil treated with $0.4 \mathrm{~mol}$ phosphoric acid $\mathrm{kg}^{-1}$ soil

$\mathrm{N} 1$ : soil treated with $0.1 \mathrm{~mol}$ mono-ammonium phosphate $\mathrm{kg}^{-1}$ soil

$\mathrm{N} 2$ : soil treated with $0.2 \mathrm{~mol}$ mono-ammonium phosphate $\mathrm{kg}^{-1}$ soil

N3: soil treated with $0.4 \mathrm{~mol}$ mono-ammonium phosphate $\mathrm{kg}^{-1}$ soil

Fig. 3. Concentrations of $\mathrm{Cd}$ in the exchangeable $\left(\mathrm{Cd}_{\mathrm{Ex}}\right)$ fraction and bound to iron and manganese oxides $\left(\mathrm{Cd}_{\mathrm{FeOx}+\mathrm{MnOy}}\right)$ with different application rates of phosphoric acid and mono-ammonium phosphate (MAP). P1-P3, $0.1, \quad 0.2$ and $0.4 \mathrm{~mol}$ phosphoric acid $\mathrm{kg}^{-1}$ soil, respectively; N1-N3, 0.1, 0.2 and 0.4 mol MAP kg ${ }^{-1}$ soil, respectively. Data are the mean \pm s.d. of three observations.

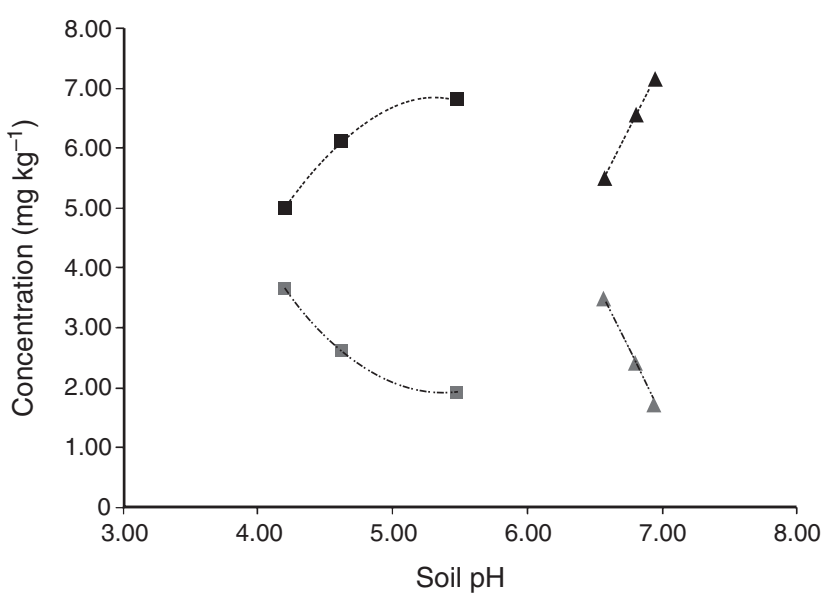

Soil $\mathrm{pH}$ and concentration of $\mathrm{Cd}(\mathrm{Ex})$ in soil treated with phosphoric acid $\Delta$ Soil $\mathrm{pH}$ and concentration of $\mathrm{Cd}(\mathrm{Ex})$ in soil treated with MAP

- Soil pH and concentration of $\mathrm{Cd}(\mathrm{FeOx}+\mathrm{MnOy})$ in soil treated with phosphoric acid

$\Delta$ Soil $\mathrm{pH}$ and concentration of $\mathrm{Cd}(\mathrm{FeOx}+\mathrm{MnOy})$ in soil treated with MAP

Fig. 4. Relationship between soil $\mathrm{pH}$ (mean of three observations) and concentrations of $\mathrm{Cd}$ in the fractions bound to iron and manganese oxides $\left(\mathrm{Cd}_{\mathrm{FeOx}+\mathrm{MnOy}}\right)$ and exchangeable $\left(\mathrm{Cd}_{\mathrm{Ex}}\right)$ in calcareous soil treated with different levels of phosphoric acid or mono-ammonium phosphate (MAP). Data are the mean \pm s.d. of three observations.

present. However, the problem of $\mathrm{Cd}$ activation in calcareous soil with high environmental background values should not be overlooked.

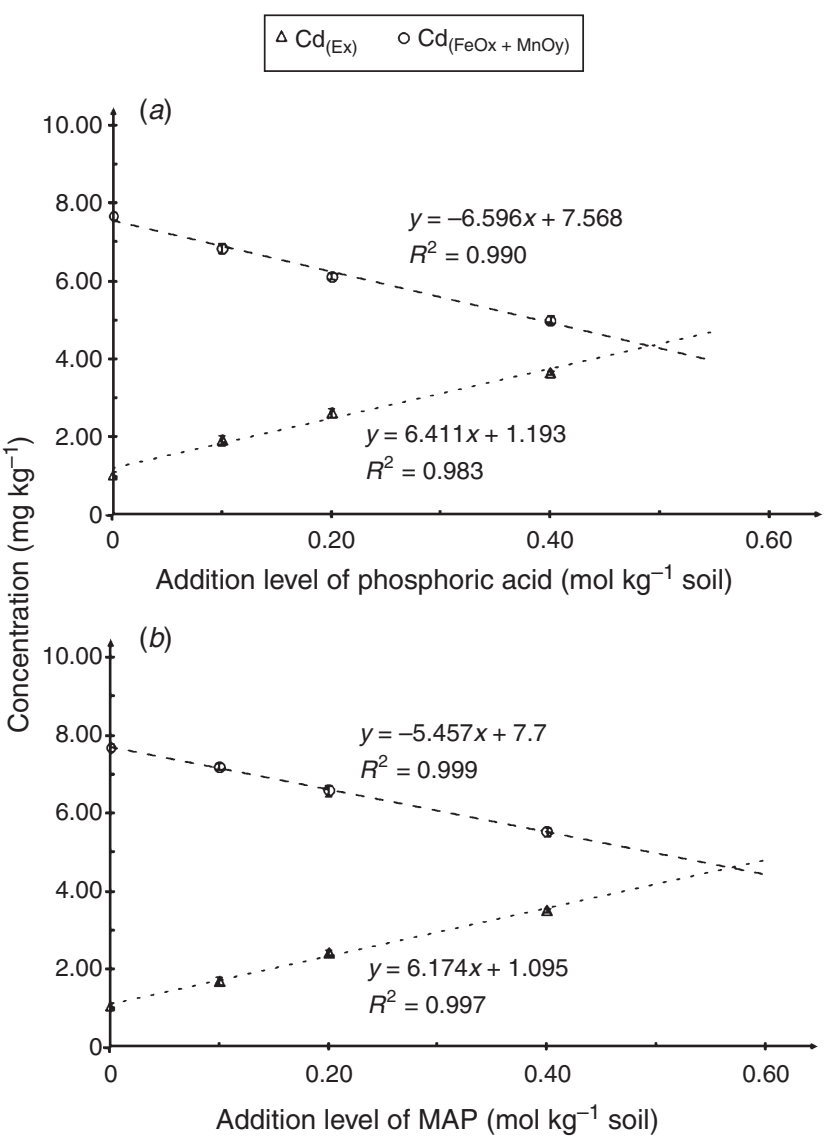

Fig. 5. Relationship between application rate ( $\mathrm{mol} \mathrm{kg}^{-1}$ soil) of the two Pcontaining acidifying agents, namely $(a)$ phosphoric acid and $(b)$ monoammonium phosphate (MAP), and concentrations of $\mathrm{Cd}$ in the fractions bound to iron and manganese oxides $\left(\mathrm{Cd}_{\mathrm{FeOx}+\mathrm{MnOy}}\right)$ and exchangeable $\left(\mathrm{Cd}_{\mathrm{Ex}}\right)$ in the calcareous soil. Data are the mean \pm s.d. of three observations.

Both MAP and phosphoric acid are used as sources of watersoluble P. From Fig. 5 it can be seen that there was a significant linear correlation between concentrations of $\mathrm{Cd}_{\mathrm{Ex}}$ and $\mathrm{Cd}_{\mathrm{FeOx}}$ $+\mathrm{MnOy}$ and the addition rate of the two P-containing acidifying agents, and that the two acidifying agents at the same level of addition provided the same amount of $\mathrm{P}$ in water-soluble form to the calcareous soil. This indicates that the application rate of water-soluble $\mathrm{P}$ may be an important factor affecting the chemical transformation of $\mathrm{Cd}$ in calcareous soil. The increase in water-soluble $\mathrm{P}$ in calcareous soils with addition of the two P-containing acidifying agents induced the absorption of $\mathrm{Cd}$ on $\mathrm{Fe}$ oxides and the conversion of $\mathrm{P}$ in water-soluble form to the Fe-bound form (Jalali and Ranjbar 2010). This may explain the chemical transformation of $\mathrm{Cd}$ in calcareous soil treated with the two P-containing acidify agents.

To study the main factors affecting the chemical transformation of $\mathrm{Cd}$ in calcareous soil treated with the two $\mathrm{P}$-containing acidify agents, two independent variables (soil $\mathrm{pH}$ and the addition level of $\mathrm{P}$ in water-soluble form $\left.\left(P_{\text {addition }}\right)\right)$ were used in a multiple stepwise regression analysis. The results (see Eqns 1 and 2) indicated that only $P_{\text {addition }}$ remained as a statistically significant predictor variable $(P<0.05)$ : 


$$
\begin{gathered}
\mathrm{Cd}_{\mathrm{Ex}}=6.206 \times P_{\text {addition }}+1.254 \\
\left(R^{2}=0.983 ; \mathrm{SE}=0.137\right) \\
\mathrm{Cd}_{\mathrm{FeOx}+\mathrm{MnOy}}=-6.437 \times P_{\text {addition }}+7.520 \\
\left(R^{2}=0.990 ; \mathrm{SE}=0.107\right)
\end{gathered}
$$

where $\mathrm{Cd}_{\mathrm{Ex}}$ is the concentration of exchangeable $\mathrm{Cd}$ in $\mathrm{mg} \mathrm{kg}^{-1}$, $\mathrm{Cd}_{\mathrm{FeOx}+\mathrm{MnOy}}$ is the concentration of $\mathrm{Cd}$ in the form of bound to iron and manganese oxides in $\mathrm{mg} \mathrm{kg}^{-1}$ and $P_{\text {addition }}$ is the addition level of $\mathrm{P}$ in water-soluble form in $\mathrm{mol} \mathrm{kg}^{-1}$ soil. From Eqns 1 and 2 it can be seen that the two models had a high coefficient of determination $\left(R^{2}\right)$ and a small standard error of the estimate (SE), which means the chemical transformation of $\mathrm{Cd}$ in calcareous soil treated with the two P-containing acidify agents was mainly associated with the addition level of $\mathrm{P}$ in water-soluble form and not soil $\mathrm{pH}$. However, several studies have reported that water-soluble phosphate compounds can immobilise $\mathrm{Cd}$ through various mechanisms, such as surface complexation, ion exchange, precipitation and adsorption (LeviMinzi and Petruzzelli 1984; Pearson et al. 2000; McGowen et al. 2001; Bolan et al. 2003; Thawornchaisit and Polprasert 2009). Further research is needed to investigate the mechanism of chemical transformation of $\mathrm{Cd}$ in calcareous soil treated with the two P-containing acidify agents.

Numerous studies have shown that the use of phosphate fertilisers can control plant accumulation of Cd (Takijima and Katsumi 1973; MacLean 1976; Williams and David 1976; Street et al. 1978). However, the present study suggests that MAP applied as a phosphate fertiliser cannot reduce the availability of $\mathrm{Cd}$ in calcareous soil and should therefore be used carefully in the study area and in other regions with similar conditions.

\section{Conclusions}

The concentration of total $\mathrm{Cd}$ in the calcareous soil of the study area was very high and most of the $\mathrm{Cd}$ in the soil was only slightly available, being primarily bound to Fe and Mn oxides. Phosphoric acid is a strong P-containing acidifying agent that can significantly decrease the $\mathrm{pH}$ of the calcareous soil at a low application rate, whereas MAP is a weak P-containing acidifying agent and acidifying fertiliser that can slightly decrease the $\mathrm{pH}$ of the soil at normal application rates with its higher acid buffering capacity. However, both P-containing acidifying agents can markedly and effectively promote the conversion of $\mathrm{Cd}_{\mathrm{FeOx}+\mathrm{MnOy}}$ to $\mathrm{Cd}_{\mathrm{Ex}}$. The amount of $\mathrm{Cd}_{\mathrm{FeOx}+\mathrm{MnOy}}$ converted to $\mathrm{Cd}_{\mathrm{Ex}}$ was significantly correlated with the addition rate of the two acidifying agents, and the increase in water-soluble $\mathrm{P}$ in the calcareous soil with the addition of acidifying agent induced the adsorption of $\mathrm{Cd}$ on $\mathrm{Fe}$ oxides. Considerable attention should be paid to the problem of $\mathrm{Cd}$ activation in calcareous soils with application of the two acidifying agents.

\section{Acknowledgements}

This research was funded, in part, by a project supported by the Key Laboratory of Soil Environment, the Environmental Protection Research Project of Jiangsu Province (Grant no. 201264) and Pollution Remediation and the National Natural Science Foundation of China (Grant no. 41001315). The authors thank all their colleagues who helped with the collection and analysis of the soil samples. The authors are very grateful to Dr Peter Christie (Belfast, UK) for his revision of the manuscript.

\section{References}

Abbaspour A, Kalbasi M, Hajrasuliha SH, Golchin A (2007) Effects of plant residue and salinity on fractions of cadmium and lead in three soils. Soil and Sediment Contamination 16, 539-555. doi:10.1080/15320380 701623313

Agency for Toxic Substances and Disease Registry (2008) 'Draft toxicological profile for cadmium.' (US Department of Health and Human Services, Public Health Service Agency for Toxic Substances and Disease Registry: Atlanta, GA)

Agricultural Chemistry Committee of China (1983) 'Conventional methods of soil and agricultural chemistry analysis.' (Science Press: Beijing) [in Chinese]

Ahnstrom ZS, Parker DR (1999) Development and assessment of a sequential extraction procedure for the fractionation of soil cadmium. Soil Science Society of America Journal 63, 1650-1658. doi:10.2136/ sssaj1999.6361650x

Allison LE, Moodie CD (1965) Carbonate. In 'Methods of soil analysis, Part II'. (Eds CA Black, DD Evans, LE Ensminger, JL White, FE Clark) pp. 1379-1396. (American Society of Agronomy: Madison, WI)

Andreu V, Gimeno-Garcia E (1996) Total content and extractable fraction of cadmium, cobalt, copper, nickel, lead, and zinc in calcareous orchard soils. Communications in Soil Science and Plant Analysis 27, 2633-2648. doi:10.1080/00103629609369728

Basta NT, Gradwohl R, Snethen KL, Schroder JL (2001) Chemical immobilization of lead, zinc, and cadmium in smelter-contaminated soils using biosolids and rock phosphate. Journal of Environmental Quality 30, 1222-1230. doi:10.2134/jeq2001.3041222x

Bloemen ML, Markert B, Lieth H (1995) The distribution of $\mathrm{Cd}, \mathrm{Cu}$, $\mathrm{Pb}$, and $\mathrm{Zn}$ in topsoils of Osnaruck in relation to land use. The Science of the Total Environment 166, 137-148. doi:10.1016/00489697(95)04520-B

Bolan NS, Adriano DC, Duraisamy P, Mani A, Arulmozhiselvan K (2003) Immobilization and phytoavailability of cadmium in variable charge soils. I: effect of phosphate addition. Plant and Soil 250, 83-94. doi:10.1023/A:1022826014841

Cornu S, Neal C, Ambrosi JP, Whitehead P, Neal M, Sigolo J, Vachier P (2001) The environmental impact of heavy metals from sewage sludge in ferralsols (Sao Paulo, Brazil). The Science of the Total Environment 271, 27-48. doi:10.1016/S0048-9697(00)00814-7

CSTCR- GISSCAS (Chinese Soil Taxonomy Cooperative Research Group, Institute of Soil Science, Chinese Academy of Sciences) (1995) 'Chinese soil taxonomy.' (Chinese Agricultural Science and Technology Press: Beijing) [in Chinese]

Friberg L, Piscator M, Nordberg GF (1974) 'Cadmium in the environment.' (Chemical Rubber Co.: Cleveland, $\mathrm{OH}$ )

Gharaibeh MA, Eltaif NI, Shraáh SH (2010) Reclamation of a calcareous saline-sodic soil using phosphoric acid and by-product gypsum. Soil Use and Management 26, 141-148. doi:10.1111/j.1475-2743.2010. 00260.x

Gibbs RJ (1973) Mechanisms of trace metal transport in rivers. Science 180, 71-73. doi:10.1126/science.180.4081.71

Guo ZH, Liao BH, Huang CY (2005) Mobility and speciation of $\mathrm{Cd}, \mathrm{Cu}$, and $\mathrm{Zn}$ in two acidic soils affected by simulated acid rain. Journal of Environmental Sciences 17, 332-334.

Guo JH, Liu XJ, Zhang Y, Shen JL, Han WX, Zhang WF, Christie P, Goulding KWT, Vitousek PM, Zhang FS (2010) Significant acidification in major Chinese croplands. Science 327, 1008-1010. doi:10.1126/ science. 1182570

Haghiri F (1974) Plant uptake of cadmium as influenced by cation exchange capacity, organic matter, zinc, and soil temperature. Journal of 
Environmental Quality 3, 180-183. doi:10.2134/jeq1974.00472425 $000300020021 \mathrm{x}$

Jalali M, Khanlari ZV (2008) Cadmium availability in calcareous soils of agricultural lands in Hamadan, Western Iran. Soil and Sediment Contamination 17, 256-268. doi:10.1080/15320380802006970

Jalali M, Ranjbar F (2010) Aging effects on phosphorus transformation rate and fractionation in some calcareous soils. Geoderma 155, 101-106. doi:10.1016/j.geoderma.2009.11.030

John MK, Chuah HH, van Laerhoven J (1972) Cadmium contamination of soil and its uptake by oats. Environmental Science \& Technology $\mathbf{6}$, 555-557. doi:10.1021/es60065a001

Khanmirzaei A, Bazargan K, Amir Moezzi A, Richards BK, Shahbazi K (2013) Single and sequential extraction of cadmium in some highly calcareous soils of southwestern Iran. Journal of Soil Science and Plant Nutrition 13, 153-164.

Kim AY, Kim JY, Ko MS, Kim KW (2010) Acid rain impact on phytoavailability of heavy metals in soils. Geosystem Engineering 13, $133-138$.

Lafuente AL, González C, Quintana JR, Vázquez A, Romero A (2008) Mobility of heavy metals in poorly developed carbonate soils in the Mediterranean region. Geoderma 145, 238-244. doi:10.1016/ j.geoderma.2008.03.012

Levi-Minzi R, Petruzzelli G (1984) The influence of phosphate fertilizers on Cd solubility in soil. Water, Air, and Soil Pollution 23, 423-429. doi:10.1007/BF00284737

Lim TT, Tay JH, The CI (2002) Contamination time effect on lead and cadmium fractionation in a tropical coastal clay. Journal of Environmental Quality 31, 806-812. doi:10.2134/jeq2002.0806

Lu JL (2000) 'Plant nutrition.' (China Agricultural University Press: Beijing) [in Chinese]

Lu A, Zhang S, Shan X (2005) Time effect on the fractionation of heavy metals. Geoderma 125, 225-234. doi:10.1016/j.geoderma.2004. 08.002

Ma YB, Uren NC (1998) Transformation of heavy metals added to soilapplication of a new sequential extraction procedure. Geoderma 84, 157-168. doi:10.1016/S0016-7061(97)00126-2

MacLean AJ (1976) Cadmium in different plant species and its availability in soils as influenced by organic matter and addition of lime, P, Cd and Zn. Canadian Journal of Soil Science 56, 129-138. doi:10.4141/ cjss76-021

Mann SS, Ritchie GSP (1993) The influence of $\mathrm{pH}$ on the forms of cadmium in four West Australian soils. Australian Journal of Soil Research 31, 255-270. doi:10.1071/SR9930255

Mann SS, Ritchie GSP (1994) Changes in the forms of cadmium with time in some western Australian soils. Australian Journal of Soil Research 32, 241-250. doi:10.1071/SR9940241

McGowen SL, Basta NT, Brown GO (2001) Use of diammonium phosphate to reduce heavy metal solubility and transport in smelter-contaminated soil. Journal of Environmental Quality 30, 493-500. doi:10.2134/ jeq2001.302493x

Naidu R, Bolan NS, Kookana RS, Tiller KG (1994) Ionic strength and pH effects on the sorption of cadmium and the surface charge of soils. European Journal of Soil Science 45, 419-429. doi:10.1111/j.13652389.1994.tb00527.x

Navarro-Pedreño J, Almendro-Candel MB, Jordán-Vidal MM, MataixSolera J, García-Sánchez E (2003) Mobility of cadmium, chromium, and nickel through the profile of a calcisol treated with sewage sludge in the southeast of Spain. Environmental Geology 44, 545-553. doi:10.1007/s00254-003-0790-5
Pearson MS, Maenpaa K, Pierzynski GM, Lydy MJ (2000) Effects of soil amendments on the bioavailability of lead, zinc, and cadmium to earthworms. Journal of Environmental Quality 29, 1611-1617. doi:10.2134/jeq2000.00472425002900050031x

Rajaie M, Karimian N, Maftoun M, Yasrebi J, Assad MT (2006) Chemical forms of cadmium in two calcareous soil textural classes as affected by application of cadmium-enriched compost and incubation time. Geoderma 136, 533-541. doi:10.1016/j.geoderma.2006.04.007

Segal E, Peter JS, Scott AB, Todd HS, Dennis LC (2009) Measuring particle size distribution using laser diffraction: implications for predicting soil hydraulic properties. Soil Science 174, 639-645. doi:10.1097/SS.0b013e3181c2a928

Siepak J, Walna B, Drzymała S (1999) Speciation of aluminum released under the effect of acid rain. Polish Journal of Environmental Studies $\mathbf{8}$, $55-58$.

Simard RR, Beauchemin S, Laverdière MR (1999) Limed sewage sludge effects on nutrient status and metal fractions in acidic soils. Canadian Journal of Soil Science 79, 173-182. doi:10.4141/S98-021

Soil Survey Division Staff (1993) 'Soil survey manual.' pp. 63-65. (United States Department of Agriculture)

Soil Survey Staff (1996) 'Keys to soil taxonomy.' (USDA: Washington, DC) Sposito G, Lund LJ, Chang AC (1982) Trace metal chemistry in arid-zone field soils amended with sewage sludge: I. Fractionation of $\mathrm{Ni}, \mathrm{Cu}, \mathrm{Zn}$, $\mathrm{Cd}$, and $\mathrm{Pb}$ in soil phases. Soil Science Society of America Journal 46, 260-264. doi:10.2136/sssaj1982.03615995004600020009x

Street JJ, Sabey BK, Lindsay WI (1978) Influence of $\mathrm{pH}$, phosphorus, cadmium, sewage sludge and incubation time on the solubility and plant uptake of cadmium. Journal of Environmental Quality 7, 286-290. doi:10.2134/jeq1978.00472425000700020027x

Sutherland RA, Tack FMG, Tolosa CA, Verloo MG (2000) Operationally deined metal fractions in road deposited sediment, Honolulu, Hawaii. Journal of Environmental Quality 29, 1431-1439. doi:10.2134/jeq2000. 00472425002900050009x

Takijima Y, Katsumi F (1973) Cadmium contamination of soils and rice plants caused by zinc mining. IV. Use of soil amendment materials for the control of Cd uptake by plants. Journal of Soil Science and Plant Nutrition 19, 235-244. doi:10.1080/00380768.1973.10432593

Tessier A, Campbell PGC, Bisson M (1979) Sequential extraction procedure for the speciation of particulate trace metals. Analytical Chemistry 51, 844-851. doi: $10.1021 / \mathrm{ac50043a017}$

Thawornchaisit U, Polprasert C (2009) Evaluation of phosphate fertilizers for the stabilization of cadmium in highly contaminated soils. Journal of Hazardous Materials 165, 1109-1113. doi:10.1016/j.jhazmat.2008. 10.103

Udom BE, Mbagwu JSC, Adesodun JK, Agbim NN (2004) Distribution of zinc, copper, cadmium and lead in a tropical Ultisol after long-term disposal of sewage sludge. Environment International 30, 467-470. doi:10.1016/j.envint.2003.09.004

Walter I, Cuevas G (1999) Chemical fractionation of heavy metals in a soil amended with repeated sewage sludge application. The Science of the Total Environment 226, 113-119. doi:10.1016/S0048-9697(98)00374-X

Williams CH, David DJ (1976) The accumulation in soil of cadmium residues from phosphate fertilizers and their effect on the cadmium content of plants. Soil Science 121, 86-93. doi:10.1097/00010694197602000-00004

Yasrebi J, Karimian N, Maftoun M, Abtahi A, Sameni AM (1994) Distribution of zinc forms in highly calcareous soils as influenced by soil physical and chemical properties and application of zinc sulfate. Communications in Soil Science and Plant Analysis 25, 2133-2145. doi:10.1080/00103629409369177 